\title{
The Geography of Sport in Finland
}

\author{
By Seppo Suominen ${ }^{*}$
}

\begin{abstract}
The main purpose of this study is to answer: Why do teams survive in some locations?How many top teams can a particular town can sustain?How differentiated are these towns in terms of different sports?. The purpose is thus to link geography and the number of teams in a town. The monopolistic competition of Dixit \& Stiglitz (1977) seems to be compatible with the sports geography in Finland. Location attributes and team success are important in determining attendance. These are in the long run the major determinants of survival in the highest level of any ball game in Finland. Geography is related to town population and their incomes. The Dixit-Stiglitz model also proposes that the attendance or the number of spectators is more related and correlated with the cost structure of the team than with the population statistics. The results seem to verify this hypothesis. The monopolistic competition model is tested with Finnish data covering 26 seasons starting in 1990. The data incorporates top team playing in the highest men's league. These popular ball games in this study are ice hockey, football, baseball, floorball, volleyball and basketball. Two estimation methods are used. The Poisson regression and Negative Binomial regression both yield similar results. A larger town in terms of population is able to sustain a larger number of different sports while the average income of citizens is negatively related to the number of sport teams in that town. It is also true that the biggest city of a region seems to cannibalise its neighbouring towns and these have a smaller number of teams.
\end{abstract}

Keywords: Sport geography, Finland, Dixit-Stiglitz, Men's top team sport, ice hockey, football, baseball, floorball, volleyball and basketball.

\section{Introduction and Motivation}

The geography of sport in Finland shows that most of the top league teams in men's ice hockey or floorball are located in large cities, while the best teams in Finland's traditional sport of pesäpallo (baseball) are based in more rural localities. During the period from 1990 to 2015, men's ice hockey has been played in 15 different cities, which includes a period when the league was closed and there was no promotion or relegation. Other popular team sport leagues were not closed during the sample period yet the locations of the teams in those leagues have remained rather stable.

The stability regarding of the locations of the teams raises the questions: Why do teams survive in some locations? How many top teams can a particular town sustain? How differentiated are these towns in terms of different sports?

${ }^{*}$ Professor, Haaga-Helia University of Applied Sciences, Finland. 
A standard explanation for such stability is that only the weakest teams are subject to relegation and that the better teams do not drop. However, during the long sample period, all the teams (except for some years in ice hockey) could have been relegated at one point or another and because no team has always been dominant this leads to the suggestion that there could have been greater variations in location.

The results of the paper show that a larger town in terms of population is needed in order to sustain top teams in the long run. If a particular team relegates the large population of a town enables to push up another team from the same town within a short time period. However, there are differences across sports. The costs of an ice hockey team are higher than those of a floorball team. Therefore only the largest towns in Finland are able to sustain top ice hockey teams while substantially smaller population is enough for others like floorball or basketball. Surprisingly the average household incomes have a negative effect on sustainability.

First some preliminary statistics is presented covering six different sports in Finland: ice hockey, football, baseball (Finnish type), floorball, volleyball, and basketball. Only male top teams are used in the analysis since the spectator number of these male sports is substantially higher than the respective number in female sports. Relevant literature is presented next. A simplified version of the Dixit-Stiglitz model (1977) is used to justify the variables in the estimation. Both a Poisson and Negative Binomial regression methods are used in estimation and finally the results are evaluated. The average minimum population size is calculated for each sport.

\section{Preliminary Statistics}

This study uses data covering 26 seasons from 1990 (or 1990/91) to 2015 (or 2015/2016). Six main sports are used in the analysis: Ice hockey, Football, Baseball, Floorball, Volleyball and Basketball. The location of each team is identified. Table 1 presents some statistics on the locations of the top teams in six different sports.

Floorball has been even more concentrated in the Helsinki area, resulting in a Herfindahl-Hirschman index of 1124. The share of Helsinki teams in the floorball league throughout the period is $78 / 328=23.8 \%$. However, there has been considerable turnover in the number of different Helsinki teams playing floorball in the top league, which amounts to 11 . Nevertheless, floorball is a slightly more urban than ice hockey as Table one shows. Baseball and volleyball seem to be played in the smallest towns in Finland. And although these sports have had top teamsfrom Helsinki, the median town size for those sports, as measured by 2005 population, has been 21885 for baseball and 24243 for volleyball. Football and basketball lie between big city sports (floorball and ice hockey) and small town sport (baseball and volleyball) in terms of town population. 
Table 1. Descriptive Statistics, Locations of Top Teams for 26 Seasons 19902015 or 1990/91 - 2015/2016

\begin{tabular}{|l|c|c|c|c|c|c|}
\hline & $\begin{array}{c}\text { Ice } \\
\text { hockey } \\
\# 340\end{array}$ & $\begin{array}{c}\text { Football } \\
\# 327\end{array}$ & $\begin{array}{c}\text { Baseball } \\
\# 337\end{array}$ & $\begin{array}{c}\text { Floorball } \\
\# 328\end{array}$ & $\begin{array}{c}\text { Volleyball } \\
\# 282\end{array}$ & $\begin{array}{c}\text { Basketball } \\
\# 323\end{array}$ \\
\hline $\begin{array}{l}\text { Regular } \\
\text { number } \\
\text { of teams } \\
\text { in highest } \\
\text { league }\end{array}$ & $12-15$ & $10-14$ & $11-15$ & $10-14$ & $8-12$ & $10-16$ \\
\hline $\begin{array}{l}\text { Different } \\
\text { teams }\end{array}$ & 18 & 33 & 28 & 46 & 33 & 27 \\
\hline $\begin{array}{l}\text { Different } \\
\text { towns }\end{array}$ & 15 & 23 & 27 & 23 & 24 & 21 \\
\hline $\begin{array}{l}\text { HHI } \\
\text { (towns) }\end{array}$ & 935 & 719 & 519 & 1124 & 640 & 610 \\
\hline $\begin{array}{l}\text { Pop 2005, } \\
\text { min }\end{array}$ & 31190 & 10716 & 3414 & 7413 & 3834 & 7844 \\
\hline $\begin{array}{l}\text { Pop 2005, } \\
25 \%\end{array}$ & 59017 & 22233 & 9886 & 57085 & 14035 & 18083 \\
\hline $\begin{array}{l}\text { Pop 2005, } \\
\text { median }\end{array}$ & 122720 & 76191 & 21885 & 174984 & 24243 & 54802 \\
\hline $\begin{array}{l}\text { Pop 2005, } \\
75 \%\end{array}$ & 174984 & 127337 & 37374 & 203029 & 57617 & 174984 \\
\hline $\begin{array}{l}\text { Pop 2005, } \\
\text { max }\end{array}$ & 560905 & 560905 & 560905 & 560905 & 560905 & 560905 \\
\hline
\end{tabular}

Note: The number of observations varies from 282 (volleyball) to 340 (ice hockey).

Helsinki (population in 2005 was 560,905) has had two teams in the ice hockey league for most of the period covered and Tampere has always had two representatives (population 204,337). The aggregate number of observations in Helsinki is 50 (one team 26 seasons and the other 24 seasons) and in Tampere 52 (two teams and 26 seasons). Helsinki's share $\left(\mathrm{s}_{\mathrm{H}}\right)$ throughout the period is thus $50 / 340=14.7 \%$. The Herfindahl-Hirschman index $\left(H=\sum_{i=1990 / 91}^{2015 / 26} s_{i}^{2}\right)$ measuring the concentration of ice hockey top teams is 0.0935 or 935 .

There are three towns that have had at least one team in the highest league in all six different sports: Helsinki, Jyväskylä $(124,205)$ and Tampere. The population has varied between 72,292 and 231,704 among those towns that have simultaneously had teams in five different sports. The other figures are presented in Table 2. 
Table 2. Population Statistics for Towns that have had at Least One Team in the Highest Men's League of any one of Six Different Sports

\begin{tabular}{|l|c|c|c|c|c|c|}
\hline Size of town & $\begin{array}{c}6 \text { sports } \\
\# 3\end{array}$ & $\begin{array}{c}5 \text { sports } \\
\# 4\end{array}$ & $\begin{array}{c}4 \text { sports } \\
\# 3\end{array}$ & $\begin{array}{c}3 \text { sports } \\
\# 6\end{array}$ & $\begin{array}{c}2 \text { sports } \\
\# 9\end{array}$ & $\begin{array}{c}1 \text { sport } \\
\# 40\end{array}$ \\
\hline Min & 124205 & 72292 & 89924 & 53965 & 10780 & 3414 \\
\hline Median & 342555 & 204337 & 173436 & 71435 & 40381 & 17058 \\
\hline Max & 560905 & 231704 & 187281 & 98413 & 61889 & 54728 \\
\hline Simultaneously & & 5 sports & 4 sports & 3 sports & 2 sports \\
$\# 3$ & $\begin{array}{c}\# 5 \\
\text { sport } \\
\# 43\end{array}$ \\
\hline Min & -- & 124205 & 72292 & 53965 & 17300 & 3419 \\
\hline Median & -- & 204337 & 174868 & 87190 & 53672 & 16198 \\
\hline Max & -- & 560905 & 231704 & 104625 & 64271 & 54728 \\
\hline
\end{tabular}

In the sample we have 66 towns that have had at least one team in the highest league of the following sports: ice hockey, football, baseball, floorball, volleyball or basketball. The statistics reveal that a town size of about 45000 70000 inhabitants can sustain one, two, three, four or even five different sports at the highest level.

Three Finnish towns - Helsinki, Tampere, Jyväskylä - were also able to simultaneously sustain 5 different sports. However, most of the towns listed were only able to simultaneously sustain one (43 towns) or two (9 towns) sports in a top league. Nevertheless, there were 16 towns in Finland that were able to sustain simultaneously three or more different sports. Those observations suggest that it is possible that the spectators of one sport might not overlap with the spectators for another sport, in particular, baseball seems to be an outlier based on the correlation statistics for spectators presented in Table 3.

Table 3. Popularity of Team Sports, "Has Attended at Least One Game during the Last Year?" and Correlation Matrix,

\begin{tabular}{|l|l|l|l|l|l|l|l|}
\hline & Popularity & $\begin{array}{l}\text { Ice } \\
\text { hockey }\end{array}$ & Football & Baseball & Floorball & Volleyball & Basketball \\
\hline $\begin{array}{l}\text { Ice } \\
\text { hockey }\end{array}$ & $25.5 \%$ & 1 & 0.323 & 0.098 & 0.162 & 0.113 & 0.113 \\
\hline Football & $16.8 \%$ & & 1 & 0.056 & 0.156 & 0.087 & 0.149 \\
\hline Baseball & $5.0 \%$ & & & 1 & 0.059 & 0.063 & 0.038 \\
\hline Floorball & $3.8 \%$ & & & & 1 & 0.109 & 0.127 \\
\hline Volleyball & $3.4 \%$ & & & & & 1 & 0.085 \\
\hline Basketball & $3.0 \%$ & & & & & & 1 \\
\hline
\end{tabular}

Source: Adult sports survey 2005-2006 (Kansallinenliikuntatutkimus), $\mathrm{n}=5510$

Ice hockey seems to be the most popular sport since roughly $25 \%$ of all adult Finns visited an ice hockey game at least once in 2005 and 2006. Football came second and the figures show that those two sports are far more popular than the others listed in Table 3. Baseball in Finland is not similar to the game played in USA, although the basis of Finnish baseball comes from the USA. The correlation statistics in Table 3 show that baseball spectators do overlap at least with some other team sports. Football and ice hockey overlap the most 
and are therefore complementary since the football and ice hockey seasons are different; the regular football season usually begins in April and ends in October while the ice hockey season begins in September and ends in April. Football and Baseball are played outdoors and their seasons start in spring and end in autumn. The other sports in this study have their regular seasons from autumn to spring.

\section{Literature}

Literature concerning the geography of sport is rather scarce. Using Finnish data, there are some reports on the birth places of individual sportsmen (Tirri, 2015) and about the spread of football (Kumpulainen, 2012) but no model that explains why some towns are able to sustain more top teams than others. In professional sports in the USA teams are given a franchise by the national league organisation. Using NHL data Jones \& Ferguson (1988) show that the major attributes that have an impact on the chances of franchise survival are population and location in Canada. The quality of a location is the key element in determining a team's revenue. Even if a team's quality may not be affected by a poor location in the short run, a better location and better team quality are correlated in the long run.

Coates \& Humphreys (1997) show that a sports environment and real income growth are negatively interrelated. Chapin (2000) and Newsome \& Comer (2000) emphasize that since the Second World War, sport facilities or venues have been built in suburban locations but not in city centres, however, since the 1980s most of the new professional sport venues have been located in central city areas, although such locations are rather expensive to acquire. Nevertheless, city centre locations are easily accessible by transportation means other than one's own automobile and fans are increasingly middle and upper middle class consumers who have settled in city centres rather than suburban regions. Siegfried \& Zimbalist $(2000,2006)$ and Coates \& Humphreys (2008) reviewed the relevant literature which evaluates the economic effects of subsidies for professional sport arenas and found no evidence that arenas have had any positive effects on local economic development, income growth or job creation.

Oberhofer, et al. (2015) use German football data to show that financial resources have a positive impact on survival in the highest league (Bundesliga), while the local market size measured by population has a low but negative effect on survival. They also point out that European sport leagues are generally characterized by a system of relegation and promotion, while the American leagues are closed. A team's relegation is usually associated with a team's (low) budget, its local market size, the team's past performance and age.

Since literature is scarce on the maintainability of top sports teams in a town, a model that can explain the relationship between the number of top teams and a town's characteristics is needed. A monopolistic competition 
model and Poisson and Negative Binomial regression models are used to investigate the relationship between town size and those sports which offer the opportunity to play in the highest league.

\section{The Model}

The monopolistic competition assumption is suitable for analysing the equilibrium number of different top league sports teams (brands) in a town. Following Shy (1995) a simplified version of the Dixit \& Stiglitz (1977) model is used to analyse a town with differentiated sport teams (brands) $i=1,2,3, \ldots$, $N$. The number of sports teams $n$ is determined endogenously and $q_{i} \geq 0$ is the attendance at a sporting event (the quantity consumed of brand $i$ ) and $p_{i}$ is the ticket price (price of one unit of brand $i$ ). In a town there is a single, representative, consumer whose preferences denote a preference for variety. The utility function of the spectator is given by a CES (constant elasticity of substitution) utility function:

(1) $u\left(q_{1}, q_{2}, q_{3}, \ldots\right)=\sum_{i=1}^{N} \sqrt{q_{i}}$

The marginal utility of each brand is infinite at a zero consumption level indicating that the utility function expresses taste for variety.

(2) $\lim _{q_{i} \rightarrow 0} \frac{\partial u}{\partial q_{i}}=\lim _{q_{i} \rightarrow 0} \frac{1}{2 \sqrt{q_{i}}}=\infty$

The indifference curves are convex at the point of origin, meaning that sport spectators favour mixing the brands in their consumption. Due to the summary procedure of the utility function, it is possible that spectators gain utility even when some brands are not consumed. The representative consumer's income is made up of total wages paid by the firms producing these brands and the sum of their profits. The wage rate is normalised to equal 1 , hence all monetary values are all denominated in units of labour. The budget constraint is then:

$$
\sum_{i=1}^{N} p_{i} q_{i} \leq I=L+\sum_{i=1}^{N} p_{i} q_{i}
$$

Where L denotes labour supply.The sport spectators maximise their utility (1) subject to budget constraints (3). The Lagrangian $(E)$ is the following.

$$
L\left(q_{i}, p_{i}, \lambda\right)=\sum_{i=1}^{N} \sqrt{q_{i}}-\lambda\left[I-\sum_{i=1}^{N} p_{i} q_{i}\right]
$$

The first order condition for every brand $i$ is 


$$
\frac{\partial L}{\partial q_{i}}=\frac{1}{2 \sqrt{q_{i}}}-\lambda p_{i}=0, \quad i=1,2, \ldots . N
$$

The demand and price elasticity $\left(\varepsilon_{i}\right)$ for each brand are given $i$ by

(6) $\quad q_{i}\left(p_{i}\right)=\frac{1}{4 \lambda^{2}\left(p_{i}\right)^{2}}, \varepsilon_{i}=\frac{\partial q_{i}}{\partial p_{i}} \frac{p_{i}}{q_{i}}=-2$

It is assumed that the Lagrange multiplier $\lambda$ is a constant. Each brand is produced by a single sport club. All clubs have an identical cost structure with increasing returns to scale. Formally, the cost function $\left(C_{i}\right)$ of a sports club producing $q_{i}$ units of brand $i$ is given by

$$
C_{i}\left(q_{i}\right)=F+c q_{i} \text {, if } q_{i}>0 \text {, or } C_{i}\left(q_{i}\right)=0 \text {, if } q_{i}=0
$$

Each sport club behaves as a monopoly over its brand and maximises its profit (8)

$$
\max _{q_{i}} \pi_{i}=p_{i}\left(q_{i}\right) q_{i}-\left(F+c q_{i}\right)
$$

In the monopolistic competition model, the free entry of clubs will result in each club making zero profits in the long run and each club has excess capacity. The demand for each club producing brands (sport events) depends on the number of brands in the town, $\mathrm{N}$. As $\mathrm{N}$ increases, the demand for each club shifts downward indicating that sport spectators substitute higher consumption levels of each brand with a lower consumption spread over a larger number of brands. The free entry of clubs increases the brands until the demand curve of each club becomes tangent to the club's average cost function. At this point, entry into the sports market stops and each club makes zero profit and produces on the downward slope of the average cost curve. Due to the fact that each club has some production and maximises its profit, the marginal costs must equal marginal revenue.

$$
M C\left(q_{i}\right)=M R_{i}\left(q_{i}\right)=p_{i}\left(1+\frac{1}{\varepsilon_{i}}\right)=p_{i}\left(1+\frac{1}{-2}\right)=\frac{p_{i}}{2}=c
$$

Therefore, at equilibrium, the brand price is twice the marginal cost: $p_{i}=2 c$. The zero profit condition denotes that $q_{i}=F / c$. The labour market equilibrium presumes that labour supply (L) equals the labour demanded for production: $\sum_{i=1}^{N}\left(F+c q_{i}\right)=L$ which implies that $N\left[F+c\left(\frac{F}{c}\right)\right]=L$. The monopolistic competition equilibrium is therefore given by

$$
p_{i}=2 c \text { and } q_{i}=\frac{F}{c} \text { and } N=\frac{L}{2 F}
$$


The Dixit-Stiglitz model presented above implies that when fixed costs (F) are high, the number of brands offered in a town is low but each brand is produced in a large club. If the town is small in terms of labour supply, the number of brands is also low and there is a minor variety of different brands offered. The following hypotheses can be presented.

H1: If the town is small in terms of population $(L)$, the variety of sports offered in a town is small $(N)$.

$\mathrm{H} 2$ : When fixed costs $(F)$ are high due to the requirements of the sports, the variety of sports offered in a town is low $(N)$.

These fixed costs are related to building and maintaining a sports venue or to the number of players and other staff, like coaches or physiotherapists needed for the sport. In some sports, like ice hockey, the team size is roughly four times as large as the number of players that are simultaneously allowed to be on the field which places resource requirements on a team.

H3: The number of spectators $\left(q_{i}\right)$ correlates more with fixed costs $(F)$ than with population $(L)$.

For hypothesis $\mathrm{H} 3$ the correlation analysis is more suitable than regression based statistics since correlation statisticsonly measures simultaneously and the regression analysis is associated more with a reason-outcome relationship.

The equilibrium of the Dixit-Stiglitz model is Cournot-Nash regarding prices. Each firm sets a price on the assumption that other prices do not change. Moreover, entry drives profit down to a normal level. Hence, the combination of Cournot-Nash regarding prices and zero profits determines the number of sports offered in the town. However, the monopolistic competition model does not have any criteria for defining the group of competing brands. In our model the different sports are simply assumed to form that group. The correlation coefficients in Table 3 reveal that the audiences for different sports do not strongly overlap. The form of the marginal utility function results in a representative consumer purchasing some of every brand, which is analytically rational but not sensible in real life. Despite these shortcomings, the DixitStiglitz model is still a reasonable theoretical setting with which to study the geography of sport.

\section{Estimation Method and Results}

Data on the number of top sport teams in a town are usually count data. The data contain some towns that have only once had a top team between 1990 and 2015 period, while the corresponding figure for Helsinki is 215. The mean is 29.3. There are two commonly used estimation methods for count data: Poisson regression and Negative Binomial regression (Greene 2008, 907-915). The assumption in the Poisson regression is that each observation $y_{i}$ is drawn 
from a Poisson distribution with parameter $\lambda_{\mathrm{i}}$ which is related to the explanatory variables $x_{i}$. It must be noted that $\lambda_{\mathrm{i}}$ is not related to Lagrange multiplier $\lambda$. The equation of the model is

$$
\operatorname{Prob}\left(Y=y_{i} \mid x_{i}\right)=\frac{e^{-\lambda_{i}} \lambda_{i}^{y_{i}}}{y_{i} !}, y_{i}=0,1,2, \ldots
$$

Usually a loglinear model is used to characterise $\lambda_{i}: \ln \lambda_{i}=x_{i}^{\prime} \beta$. The expected number of events and variance are given by

$$
E\left(y_{i} \mid x_{i}\right)=\operatorname{Var}\left(y_{i} \mid x_{i}\right)=\lambda_{i}=e^{x_{i}^{\prime} \beta}
$$

The Poisson model assumes that the variance equals its mean (equation 12). This is rather critical and several tests of the validity of this assumption have been presented. The NLOGIT programme that has been used in this study presents the McGullagh \& Nelder (1983) test for overdispersion which means that the variance of the response $y_{i}$ is greater than $e^{x_{i}^{\prime} \beta}$, for example $e^{x_{i}^{\prime} \beta}+\alpha g e^{x_{i}^{\prime} \beta}$. The Negative Binomial model relaxes the Poisson assumption that the mean equals the variance. The NegBin 2 form of the probability is

$$
\begin{aligned}
\operatorname{Prob}(Y & \left.=y_{i} \mid x_{i}\right)=\frac{\Gamma\left(\theta+y_{i}\right)}{\Gamma\left(y_{i}+1\right) \Gamma(\theta)} r_{i}^{y^{i}}\left(1-r_{i}\right)^{\theta}, \lambda_{i} \\
& =\exp \left(x_{i}^{\prime} \beta\right) \text { and } r_{i}=\lambda_{i} /\left(\theta+\lambda_{i}\right)
\end{aligned}
$$

The mean and variance function in the NegBin2 model are

$$
E\left(y_{i} \mid x_{i}\right)=\lambda_{i} \text { and } \operatorname{Var}\left(y_{i} \mid x_{i}\right)=\lambda_{i}\left(1+\alpha \lambda_{i}\right), w \square \text { ere } \alpha=1 / \theta
$$

The variance in the NegBin2 is quadratic in the mean and therefore more sensible than in the case of Poisson regression.

The first hypothesis is studied using a 26-year period from 1990 to 2015 and includes all six sports: ice hockey, football, baseball, floorball, volleyball and basketball. The $y_{i}$ variable is the aggregate number of teams in the highest league of these six sports from 1990 to 2015. Bigger towns naturally have the highest score: Helsinki has 214 (pop. 560,905), Espoo 83 (pop. 231,704), Tampere 176 (pop, 204,337), Vantaa 41 (pop. 187,281), Turku 92 (pop. 174,868), Oulu 72 (pop. 173,436) and Jyväskylä 97 (pop. 124,205). Espoo and Vantaa are the neighbouring cities of Helsinki and it appears that Helsinki is cannibalising their score. The other big cities listed above are the central cities in their region. The Dixit-Stiglitz model equilibrium proposes that the score $(\mathrm{N})$ is related to labour (incomes, so that wage is equalised to one), hence a relevant $x_{i}$ variable takes into account both (the logarithm of) the population and the incomes. Table 4 below presents descriptive statistics that the variables 
used in Poisson or Negative Binomial regression and Table 5 presents the results.

Table 4. Descriptive Statistics of Variables, and Correlation Coefficients, 2005 Population and 2007 Personal Incomes ( $€)$. The Population Statistics Correlate Strongly from 1990 to 2015

\begin{tabular}{|l|c|c|c|}
\hline & Min - Mean - Max & Std.Dev. & Corr, Log Incomes \\
\hline $\begin{array}{l}\text { Log } \\
\text { Population }\end{array}$ & $1.02-\mathbf{1 0 . 3 0}-13.24$ & 1.02 & 0.384 \\
\hline Log Incomes & $9.92-\mathbf{1 0 . 1 5}-10.63$ & 0.115 & \\
\hline Score & $1-\mathbf{2 9 . 3 3}-214$ & 37.860 & \\
\hline
\end{tabular}

Table 5. Poisson and Negative Binomial Regression Results

\begin{tabular}{|c|c|c|c|c|}
\hline $\mathrm{y}_{\mathrm{i}}=$ Score & Poisson & $\begin{array}{l}\text { Negative } \\
\text { Binomial }\end{array}$ & Poisson & $\begin{array}{l}\text { Negative } \\
\text { Binomial }\end{array}$ \\
\hline Log Population & $\begin{array}{c}0.924 \\
(0.023)^{* * *}\end{array}$ & $\begin{array}{c}0.749 \\
(0.092)^{* * *}\end{array}$ & & \\
\hline $\begin{array}{l}\text { Dummy: } \\
\text { Population< } \\
15000\end{array}$ & & & $\begin{array}{c}-0.318 \\
(0.135)^{*}\end{array}$ & $\begin{array}{c}-0.848 \\
(0.256)^{* * *}\end{array}$ \\
\hline $\begin{array}{l}\text { Dummy: } 15000 \\
<\text { Population< } \\
30000\end{array}$ & & & $\begin{array}{c}0.128 \\
(0.128)\end{array}$ & $\begin{array}{c}-0.504 \\
(0.256)^{*}\end{array}$ \\
\hline $\begin{array}{l}\text { Dummy: } 30000 \\
<\text { Population< } \\
50000\end{array}$ & & & ref & ref \\
\hline $\begin{array}{l}\text { Dummy: } 50000 \\
<\text { Population< } \\
100000\end{array}$ & & & $\begin{array}{c}1.207 \\
(0.121)^{* * *}\end{array}$ & $\begin{array}{c}1.068 \\
(0.355)^{\text {** }}\end{array}$ \\
\hline $\begin{array}{l}\text { Dummy: } 100000 \\
<\text { Population< } \\
200000\end{array}$ & & & $\begin{array}{c}1.809 \\
(0.122)^{* * * *}\end{array}$ & $\begin{array}{c}1.226 \\
(0.530)^{\text {** }}\end{array}$ \\
\hline $\begin{array}{l}\text { Dummy: } 200000 \\
\text { <Population }\end{array}$ & & & $\begin{array}{c}2.883 \\
(0.120)^{* * *}\end{array}$ & $\begin{array}{c}2.270 \\
(0.603)^{* * *}\end{array}$ \\
\hline Log Incomes & $\begin{array}{c}-2.417 \\
(0.245)^{* * *}\end{array}$ & $\begin{array}{c}-2.118 \\
(0.851)^{*}\end{array}$ & $\begin{array}{c}-2.291 \\
(0.259)^{* * *}\end{array}$ & $\begin{array}{c}-2.268 \\
(0.709)^{* *}\end{array}$ \\
\hline Constant & $\begin{array}{c}17.982 \\
(2.500)^{* * *}\end{array}$ & $\begin{array}{l}16.814 \\
(8.435)^{*}\end{array}$ & $\begin{array}{l}25.796 \\
(2.655)^{* * * *}\end{array}$ & $\begin{array}{l}25.956 \\
(7.288)^{* * * *}\end{array}$ \\
\hline$\alpha$ & & $\begin{array}{c}0.503 \\
(0.116)^{* * *}\end{array}$ & & $\begin{array}{c}0.324 \\
(0.074)^{* * *}\end{array}$ \\
\hline $\begin{array}{l}\text { McFadden } \\
\text { Pseudo } \mathrm{R}^{2}\end{array}$ & 0.668 & 0.370 & 0.719 & 0.269 \\
\hline$\chi^{2}$ & $1682.164^{* * *}$ & $309.444^{* * *}$ & $1810.004^{\text {**** }}$ & $190.838^{* * * *}$ \\
\hline $\begin{array}{l}\text { Overdispersion } \\
\text { tests: } \mathrm{g}=\mu_{\mathrm{i}}\end{array}$ & 3.669 & & 5.804 & \\
\hline $\begin{array}{l}\text { Overdispersion } \\
\text { tests: } \mathrm{g}=\mu_{\mathrm{i}}^{2}\end{array}$ & 1.856 & & 2.984 & \\
\hline
\end{tabular}

Note: $* * * * * *$ indicates statistical significance a $10 \%, 5 \%$ and $1 \%$ respectively. 
The Poisson and Negative Binomial regression results show that the result is positively related to town size and negatively to income. It seems that sports are not favoured by high income consumers. This result is in line with previous studies that have examined attendance at sport events (Borland \& Lye, 1992, Baimbridge, et al., 1996, Falter \& Perignon, 2000). However, several studies have reported a positive relationship between attendance and incomes (Depken, 2001, Coates \& Harrison 2005, Coates \& Humphreys 2007).

Moreover, the Dixit-Stiglitz model equilibrium proposes that $(\mathrm{H} 3)$ the number of spectators $\left(q_{i}\right)$ correlates more with fixed costs $(F)$ than with population $(L)$. Fixed costs are somewhat difficult to measure since some teams do not publish their detailed budgets; however using data from five different sports a correlation analysis can be made. Data were sourced from the official websites of the corresponding leagues. The 2014 (2014/2015) budget figures and the 2014 (2014/2015) season spectator number are used, while the population statistics are from 2005 since the population of each town has been very stable. Table 6 presents the correlation coefficients.

Table 6. Correlation Coefficients, Logarithms

\begin{tabular}{|l|c|c|c|}
\hline & Budget & Population & Spectators \\
\hline Budget & 1 & 0.331 & 0.958 \\
\hline Population & & 1 & 0.389 \\
\hline Spectators & & & 1 \\
\hline
\end{tabular}

Table 6 shows that the number of spectators does indeed correlate more with the cost variable of each team than the population statistics confirming hypothesis H3. Finally, some descriptive statistics concerning the environment and team figures in each sport are presented in Table 7.

Table 7 shows that ice hockey in Finland is more expensive in terms of team budget or the players' payroll budget than other sports. Therefore, ice hockey requires a bigger town if it is to be sustained. Unfortunately, there is a lack of information about the budgets and payroll for floorball. The figures suggest that the volleyball, basketball and baseball teams seem to require fewer financial resources and thus a small town is able to sustain these games. 
Table 7. Descriptive Statistics of Different Sports

\begin{tabular}{|c|c|c|c|c|c|c|}
\hline & Ice Hockey & Football & Baseball & Floorball & Volleyball & Basketball \\
\hline Population & $\begin{array}{l}40381-143809 \\
-560905\end{array}$ & $\begin{array}{c}10780-113605 \\
-560905\end{array}$ & $\begin{array}{c}3414-65470- \\
560905\end{array}$ & $\begin{array}{c}7375-104602- \\
560905\end{array}$ & $\begin{array}{c}8672-91628- \\
560905\end{array}$ & $\begin{array}{c}8807-100434- \\
560905\end{array}$ \\
\hline Incomes & $\begin{array}{c}23291-26630- \\
37440\end{array}$ & $\begin{array}{c}24184-26537- \\
37440\end{array}$ & $\begin{array}{c}21336-25123- \\
30616\end{array}$ & $\begin{array}{c}23291-27969- \\
37440\end{array}$ & $\begin{array}{c}22885-26392- \\
37440\end{array}$ & $\begin{array}{c}22442-25992- \\
37440\end{array}$ \\
\hline $\begin{array}{l}\text { Team budget } 2014 \text {, } \\
\text { estimate }\end{array}$ & 5720000 & 1080000 & 540000 & 200000 & 260000 & 500000 \\
\hline $\begin{array}{l}\text { Payroll budget, estimate } \\
2014\end{array}$ & 1950000 & 490000 & 245000 & & & \\
\hline \# Players, estimate & 34 & 25 & 16 & 23 & 13 & 19 \\
\hline \# Players, simultaneously & 6 & 11 & 9 & 6 & 6 & 5 \\
\hline
\end{tabular}




\section{Conclusions}

The main purpose of this study is to answer why teams survive in some locations, how many top teams a town can sustain, and how differentiated these towns are in terms of different sport types. The purpose is thus to link geography and the number of teams in a town. The monopolistic competition developed by Dixit \& Stiglitz (1977) seems to be compatible with studying the geography of sports in Finland. Location attributes and team success are important in determining attendance. These are, in the long run, the major determinants of survival at the highest level of any ball game in Finland. Geography is related to town's population and income. A larger town in terms of population is able to sustain more teams and also a larger variety of sports. Somewhat surprisingly towns with lower incomes are, on average, able to sustain a bigger number of different teams. Since evidence of sport demand and negative income elasticity has been found in several studies, these results combined with those observed here are important in the location decisions of top teams. They seem to have less survival possibilities in high income towns than in low income towns and regions.

If the threshold for sustainability is $25 \%$ population level in Table 1 , then ice hockey team seems to need a population at least 60,000 in Finland in order to sustain a team in top league. The corresponding population level for sustainability in floorball is 57,000 and in football about 22,000. A population less than 20,000 is needed for basketball and volleyball and finally a baseball team is able to sustain in a town with about 10000 citizens.

The Dixit-Stiglitz model also proposes that the attendance or the number of spectators relates and correlates more with the cost structure of a team than with population statistics. The results seem to verify this hypothesis. The monopolistic competition model is tested with Finnish data that covers 26 seasons from 1990 onwards. The data incorporate teams playing in the highest male league. The popular ball games in this study are ice hockey, football, baseball, floorball, volleyball and basketball. Two estimation methods were used and the Poisson regression and Negative Binomial regression both yield similar results. A larger town in terms of population is able to sustain a larger number of different sports, while the average income of citizens is negatively related to the number of sports teams in that town. It is also true that the biggest city in a region appears to cannibalise its neighbouring towns and these have a smaller number of teams.

The estimation strategy used an aggregate number of teams from the top leagues during the long observation period from 1990 to 2015. The period is long enough for smoothing variations between the years. All sports except ice hockey (for a short period) have a system of relegation and promotion. This system results in variation across towns. Some smaller towns in which there has been only one top team may lose their only top team due to relegation. In order to avoid zero observations, the aggregate number of top teams is used. Due to that theDixit-Stiglitz model might not be suitable for explaining shorter study periods. 
The equilibrium concept of monopolistic competition model is CournotNash on prices. Each firm sets a price on the assumption that other prices do not change. Moreover, entry drives profit down to a normal level. Hence, the combination of Cournot-Nash regarding prices and zero profits accounts for the number of sports offered in a town. Hence, the number of sports offered in town is endogenous and not pre-determined.

\section{References}

Baimbridge, M., Cameron, S., \& Dawson, P. (1996). Satellite Television and the Demand for Football: A Whole New Ball Game. Scottish Journal of Political Economy, 43(3), 317-333.

Borland, Jeff \& Lye, Jenny (1992). Attendance at Australian Rules football: a panel study. Applied Economics 24, 1053-1058.

Chapin, Tim (2000): The Political Economy of Sports Facility Location: An End-ofthe-Century Review and Assessment, 10 Marquette Sports Law Journal, 10, 361 382

Coates, Dennis \& Harrison, Thane (2005).Baseball Strikes and the Demand for Attendance.Journal of Sports Economics 6, 282-302.

Coates, Dennis \& Humphreys, Brad R. (1997): The Growth Effects of Sport Franchises, Stadia and Arenas. University of Maryland Baltimore County. Working Paper 97-02

Coates, Dennis \& Humphreys, Brad R. (2007) Ticket Prices, Concessions and Attendance at Professional Sporting Events.International Journal of Sport Finance 2, 161-170.

Coates, Dennis \& Humphreys, Brad R. (2008): Do Economists Reach a Conclusion on Subsidies for Sports

Franchises, Stadiums, and Mega-Events? Working Paper Series, Paper No. 08-18. International Association of Sport Economists

Depken, Craig A. II (2001). Research notes: Fan Loyalty in Professional Sports: An Extension to the National Football League. Journal of Sports Economics 2, 275284

Dixit, Avinash K. and Joseph E. Stiglitz (1977): Monopolistic Competition and Optimum Product Diversity. American Economic Review, 67, 297-308

Falter, Jean-Marc \&Pérignon, Christophe (2000). Demand for football and intramatchwinning probability: an essay on the glorious uncertainty of sports. AppliedEconomics 32, 1757-1765.

Greene, William H. (2008): Econometric Analysis. $6^{\text {th }}$ Edition.Pearson International Edition.

Jones, J.C.H. and D.G. Ferguson (1988): Location and Survival in the National Hockey League. The Journal of Industrial Economics, 36, 443-457

Kansallinen Liikuntatutkimus 2005-2006: aikuisväestö [elektroninen aineisto]. FSD2233, versio 1.0 (2007-01-29). Espoo: Suomen Gallup [aineistonkeruu], 2006. Helsingin kaupunki, Nuori Suomi, Opetusministeriö, Suomen Kuntoliikuntaliitto, Suomen Liikunta ja Urheilu, Suomen Olympiakomitea [tuottajat]. Tampere: Yhteiskuntatieteellinen tietoarkisto [jakaja], 2007.

Kumpulainen, Harri (2012): Keskeltä läpi vai laitojen kautta?Jalkapallon alueellisen leviämisen ja suosion kehitys Helsingissä 1800-luvun lopulta 2000-luvun alkuun.(In Finnish).Master's thesis.University of Helsinki 
McGullagh, P. and J. Nelder (1983): Generalized Linear Models. Chapman and Hall Newsome, Tracy and Jonathan C. Comer (2000): Changing Intra-Urban Location Patterns of Major League Sports Facilities. The Professional Geographer, 52, $105-120$

Oberhofer, Harald, TassiloPhilippovich and Hannes Winner (2015): Firm Survival in Professional Sports: Evidence from the German Football League. Journal of Sports Economics, 16, 59-85

Shy, Oz (1995): Industrial Organization. Theory and Applications. The MIT Press.

Siegfried, John and Andrew Zimbalist (2000): The Economics of Sports Facilities and Their Communities. The Journal of Economic Perspectives, 14, 95-114

Siegfried, John and Andrew Zimbalist (2006): The Economic Impact of Sports Facilities, Teams and Mega-Events. The Australian EconomicReview, 39, 420427

Tirri, Lasse (2015): Tutkimus Suomen maajoukkueen miesjalkapalloilijoiden maantieteellisestä liikkuvuudesta. (In Finnish), Master's Thesis.University of Jyväskylä. 
